\title{
Effect of smoking, alcohol, and other factors on the selenium status of a healthy population
}

\author{
BARBARA LLOYD, ${ }^{1}$ R S LLOYD, ${ }^{2}$ AND BARBARA E CLAYTON ${ }^{1}$ \\ From the University Department of Chemical Pathology and Human Metabolism, ${ }^{1}$ and the Professorial \\ Medical Unit, ${ }^{2}$ Faculty of Medicine, University of Southampton, Southampton General Hospital, \\ Southampton SO9 $4 X Y$, UK
}

SUMMARY In a study of selenium status in 391 apparently healthy subjects resident in the south of England statistical examination of the data showed a significant effect with regard to age, smoking, alcohol, and oral contraceptives. The most important of these factors seems to be a combination of alcohol and smoking habits in men over 30. Reference ranges have been established for glutathione peroxidase activities and the concentrations of selenium in whole blood plasma and erthrocytes.

Birke $^{1}$ and Underwood ${ }^{2}$ have reviewed the importance of selenium (Se) as an essential trace element. More recent work has shown that glutathione peroxidase (GSH-Px), a selenoenzyme, is responsible for the removal of hydrogen peroxide and other organic hydroperoxides formed during cellular oxidation metabolism. This process prevents the accumulation of lipid peroxides and free radicles which have the potential to damage cell membranes. ${ }^{3}$

Several observations have pointed to a relationship, presently unexplained, between Se and heart disease. These have included studies in laboratory animals ${ }^{4}$ - for example, Van Vleet et al showed that young pigs fed a semisynthetic diet deficient in Se and vitamin $\mathrm{E}$ developed a cardiomyopathy that was clearly shown by histological techniques. ${ }^{6}$ Some evidence from epidemiological surveys in $\operatorname{man}^{78}$ seems to support the studies in animals, and several case reports have clearly shown abnormal clinical findings in proved $\mathrm{Se}$ deficiency. ${ }^{9-11}$ A report from the People's Republic of China suggested that the incidence of Keshan disease (a fatal cardiomyopathy) may be reduced by dietary supplementation with sodium selenite. ${ }^{12} \mathrm{We}$ were especially interested to read the recent publication by Salonen $e t a l$, in which they showed a significant relationship between Se concentration in serum and cardiovascular death and myocardial infarction. ${ }^{13}$

Blood Se concentrations are generally related to diet. ${ }^{2}$ The geographical distribution of soil Se varies considerably ${ }^{1}$ and consequently plant and animal 'products will reflect these concentrations. ${ }^{6}$ There have been few reports concerning the Se status of residents in the United Kingdom. ${ }^{14} 15$

The purpose of this study was, firstly, to establish reference ranges for concentrations of $\mathrm{Se}$ and GSH-Px activities in blood for apparently healthy adults living in the south of England and, secondly, the data have been analysed to determine the effect of several factors including smoking, alcohol, and the pill.

\section{Subjects and methods}

\section{SUBJECTS}

A total of 391 apparently healthy subjects living within a $\mathbf{3 0}$ mile radius of Southampton volunteered for the study. They were asked whether they were vegetarians and, for women, whether they were taking an oral contraceptive. Details of their alcohol consumption and smoking habits were recorded according to the method of Shaper et al. ${ }^{16}$ Table 1 gives full details.

\section{METHODS}

Haematological parameters were obtained using a Coulter S Plus. Initial experiments had shown that the activity of GSH-Px in blood remained stable at $4^{\circ} \mathrm{C}$ and $-20^{\circ} \mathrm{C}$ for at least five days. Samples for GSH-Px activity were therefore stored at $4^{\circ} \mathrm{C}$ and assayed within 48 hours of collection using an LKB reaction rate analyser, by the method described by Beutler $^{17}$ using $t$-butyl hydroperoxide as substrate. 
During the study two members of the laboratory staff had blood samples taken at regular intervals, since commercial quality control material was not available. The coefficient of variation for the assay was $8.7 \%$. Whole blood and plasma samples were stored at $-20^{\circ} \mathrm{C}$ and assayed for Se by hydride generation and atomic absorption..$^{18}$ The coefficient of variation was $4.6 \%$ for whole blood Se and $4.1 \%$ for plasma Se. The erythrocyte Se concentration was calculated from the difference between the concentration in whole blood and plasma, taking the haematocrit value into account. ${ }^{18}$

Table 1 Details of subjects

\begin{tabular}{|c|c|c|c|c|c|}
\hline \multirow[b]{2}{*}{ Groups } & \multicolumn{2}{|l|}{ Men } & \multicolumn{2}{|l|}{ Women } & \multirow{2}{*}{$\begin{array}{l}\text { Total } \\
\text { No of } \\
\text { Subjects }\end{array}$} \\
\hline & No & $\begin{array}{l}(\% \text { of } \\
\text { total })\end{array}$ & No & $\begin{array}{l}\text { (\% of } \\
\text { total) }\end{array}$ & \\
\hline $\begin{array}{l}\text { No of subjects } \\
\text { Mean age (years) }\end{array}$ & $\begin{array}{l}228 \\
37 \cdot 1\end{array}$ & $(58 \cdot 3)$ & $\begin{array}{l}163 \\
38 \cdot 4\end{array}$ & $(41 \cdot 7)$ & $\begin{array}{l}391 \\
37.6\end{array}$ \\
\hline $\begin{array}{l}\text { Age range (years) } \\
\text { Tobacco consumption: }\end{array}$ & $18-85$ & & $18-85$ & & $18-85$ \\
\hline Non-smokers & 153 & $(57 \cdot 5)$ & 113 & $(42 \cdot 5)$ & 266 \\
\hline Cigarette smokers & 55 & $(52.4)$ & 50 & $(47 \cdot 6)$ & 105 \\
\hline $\begin{array}{l}\text { Cigar and pipe smokers } \\
\text { Alcohol consumption: }\end{array}$ & 20 & (100) & - & & 20 \\
\hline $\begin{array}{l}\text { Non-drinkers* } \\
\text { Weekend drinkers } \\
\text { Daily drinkers }\end{array}$ & $\begin{array}{l}55 \\
88 \\
78\end{array}$ & $\begin{array}{l}(47 \cdot 4) \\
(60 \cdot 3) \\
(72 \cdot 7)\end{array}$ & $\begin{array}{l}61 \\
58 \\
30\end{array}$ & $\begin{array}{l}(52 \cdot 6) \\
(39 \cdot 7) \\
(27 \cdot 8)\end{array}$ & $\begin{array}{l}116 \\
146 \\
108\end{array}$ \\
\hline $\begin{array}{l}\text { Subjects taking oral contraceptives } \\
\text { (age 18-45) }\end{array}$ & & & 45 & $(100)$ & 45 \\
\hline
\end{tabular}

*This group also includes those subjects who drank alcohol only very occasionally.

\section{STATISTICAL ANALYSIS}

Data processing was carried out on an ICL 2970 computer, and the appropriate statistics were obtained using the SPSS package. ${ }^{19}$

\section{Results}

Although there were more men (58.3\%) than women $(41.7 \%)$ in the study, there was no significant difference between the mean ages of the two groups (table 1). These proportions were maintained approximately in the smoking categories, but more men drank alcohol.
The smoking habits and alcohol consumption of the subjects were recorded in detail, but as only 10 subjects admitted to more than 20 cigarettes each day all the cigarette smokers were combined in one group. Alcohol consumption was divided into three categories: non-drinkers, weekend drinkers, and daily drinkers. Again only 13 of those who drank alcohol daily admitted to consuming three or more pints of beer (or its equivalent) each day. None of the subjects was on a vegetarian diet. Table 2 gives the haemoglobin values.

Since each parameter was shown to have a normal distribution the reference ranges were calculated from the mean values \pm two standard deviations (table 2). The only difference observed between men and women was the erythrocyte Se concentration expressed per gram of haemoglobin. This probably reflected the significant difference in haemoglobin and erythrocyte concentrations in men and women. GSH-Px did not correlate with the Se concentrations of whole blood, erythrocytes, or plasma.

The mean concentrations of Se in whole blood and in erythrocytes were significantly lower in men and women who were over 55 (table 3 ). These differences in the older age group were not related to haemoglobin or erythrocyte concentration or GSH-Px activity. In those aged under 55 no significant differences were observed.

Alcohol had no appreciable effect on Se status in women. The mean plasma Se concentration in men who were daily drinkers, however was significantly lower when compared with the non-drinkers or the

Table 3 The effect of age on selenium and GSH-PX

\begin{tabular}{|c|c|c|c|c|}
\hline \multirow[b]{2}{*}{ Analysis } & \multicolumn{2}{|c|}{$\begin{array}{l}\text { Age group } 18-55 \\
(n=338)\end{array}$} & \multicolumn{2}{|c|}{$\begin{array}{l}\text { Age group } 56-85 \\
(n=53)\end{array}$} \\
\hline & Mean & $( \pm S D)$ & Mean & $( \pm S D)$ \\
\hline $\begin{array}{l}\text { Whole blood selenium }(\mu \mathrm{g} / \mathrm{l}) \\
\text { Plasma selenium }(\mu \mathrm{g} / \mathrm{l}) \\
\text { Erythrocyte selenium }(\mu \mathrm{g} / \mathrm{g} \mathrm{Hb}) \\
\text { GSH-Px activity }(\mathrm{U} / \mathrm{g} \mathrm{Hb})\end{array}$ & $\begin{array}{c}138.4 \\
116.4 \\
0.494 \\
19.6\end{array}$ & $\begin{array}{l}(18 \cdot 86) \\
(16 \cdot 22) \\
(0.0854) \\
(4 \cdot 86)\end{array}$ & $\begin{array}{c}* 129.5 \\
112.1 \\
0.453 \\
20.9\end{array}$ & $\begin{array}{l}(14 \cdot 67) \\
(13 \cdot 27) \\
(0.0643) \\
(4 \cdot 99)\end{array}$ \\
\hline
\end{tabular}

Selenium concentrations of whole blood and erythrocytes were found to be significantly lower. $*=0.001$ in the older age group.

Table 2 Reference ranges for selenium and glutathione peroxidase

\begin{tabular}{|c|c|c|c|c|c|c|c|c|c|}
\hline \multirow[b]{2}{*}{ Analysis } & \multicolumn{3}{|l|}{ Men } & \multicolumn{3}{|l|}{ Women } & \multicolumn{3}{|c|}{ Total No of subjects } \\
\hline & Mean & $( \pm S D)$ & $\begin{array}{l}\text { Reference } \\
\text { range }\end{array}$ & Mean & $( \pm S D)$ & $\begin{array}{l}\text { Reference } \\
\text { range }\end{array}$ & Mean & $( \pm S D)$ & $\begin{array}{l}\text { Reference } \\
\text { range }\end{array}$ \\
\hline $\begin{array}{l}\text { Whole blood selenium }(\mu \mathrm{g} / 1) \\
\text { Plasma selenium }(\mu \mathrm{g} / 1) \\
\text { Erythrocyte selenium }(\mu \mathrm{g} / \mathrm{g} \mathrm{Hb}) \\
\text { GSH-Px (U/g Hb) } \\
\text { Haemoglobin (g/dl) }\end{array}$ & $\begin{array}{l}136.4 \\
115 \cdot 6 \\
0.476 \\
20 \cdot 0 \\
15 \cdot 3\end{array}$ & $\begin{array}{l}(19 \cdot 03) \\
(15 \cdot 72) \\
(0.0831)^{*} \\
(5 \cdot 16) \\
(0.97)^{* *}\end{array}$ & $\begin{array}{l}98-174 \\
85-147 \\
0.31-0 \cdot 64 \\
10-30 \\
13 \cdot 9-17 \cdot 2\end{array}$ & $\begin{array}{l}138 \cdot 3 \\
116 \cdot 2 \\
0 \cdot 506 \\
19 \cdot 4 \\
13 \cdot 7\end{array}$ & $\begin{array}{l}(17.94) \\
(16.21) \\
(0.083) \\
(4.47) \\
(0.91)\end{array}$ & $\begin{array}{l}102-174 \\
100-149 \\
0.34-0.67 \\
11-28 \\
11 \cdot 9-15.5\end{array}$ & $\begin{array}{l}137 \cdot 2 \\
115 \cdot 8 \\
0 \cdot 489 \\
19 \cdot 8 \\
14 \cdot 6\end{array}$ & $\begin{array}{l}(18 \cdot 58) \\
(15 \cdot 91) \\
(0.084) \\
(4 \cdot 89) \\
(1 \cdot 22)\end{array}$ & $\begin{array}{l}100-174 \\
84-148 \\
0 \cdot 32-0 \cdot 66 \\
10-30 \\
12 \cdot 2-17 \cdot 0\end{array}$ \\
\hline
\end{tabular}

Significantly lower mean concentrations of erythrocyte selenium $* p=0.001$ and higher haemoglobin concentrations ${ }^{* *} p=0.0001$ were found in men. 
Table 4 Effect of alcohol consumption on selenium status in non-smoking men

\begin{tabular}{|c|c|c|c|c|c|c|}
\hline \multirow[b]{2}{*}{ Analysis } & \multicolumn{2}{|c|}{$\begin{array}{l}\text { Non-drinkers } \\
(n=43)\end{array}$} & \multicolumn{2}{|c|}{$\begin{array}{l}\text { Weekend drinkers } \\
(n=58)\end{array}$} & \multicolumn{2}{|c|}{$\begin{array}{l}\text { Daily drinkers } \\
(n=48)\end{array}$} \\
\hline & Mean & $( \pm S D)$ & Mean & $( \pm S D)$ & Mean & $( \pm S D)$ \\
\hline $\begin{array}{l}\text { Whole blood selenium }(\mu \mathrm{g} / \mathrm{l}) \\
\text { Plasma selenium }( \pm \mathrm{g} / \mathrm{l}) \\
\text { Erythrocyte selenium }( \pm \mathrm{g} / \mathrm{g} \mathrm{Hb}) \\
\text { GSH-Px }(\mathrm{U} / \mathrm{g} \mathrm{Hb})\end{array}$ & $\begin{array}{l}139 \cdot 2 \\
119 \cdot 7 \\
0.485 \\
20.7\end{array}$ & $\begin{array}{l}(22 \cdot 62) \\
(16 \cdot 19) \\
(0.095) \\
(5 \cdot 84)\end{array}$ & $\begin{array}{l}138 \cdot 6 \\
119 \cdot 7 \\
0 \cdot 477 \\
20 \cdot 3\end{array}$ & $\begin{array}{l}(14.41) \\
(12.99) \\
(0.070) \\
(4.89)\end{array}$ & $\begin{array}{c}137 \cdot 2 \\
\cdot 112 \cdot 4 \\
0 \cdot 490 \\
20 \cdot 1\end{array}$ & $\begin{array}{l}(16 \cdot 93) \\
(15 \cdot 70) \\
(0.074) \\
(5 \cdot 25)\end{array}$ \\
\hline
\end{tabular}

Mean concentration of selenium in plasma was significantly lower. ${ }^{*} \mathrm{p}=0.03$ in men who drank daily compared with each of the two other groups.

Table 5 Effect of cigarette smoking on selenium status in men in relation to age irrespective of their drinking habits

\begin{tabular}{|c|c|c|c|c|c|c|c|c|}
\hline \multirow[b]{2}{*}{ Analysis } & \multicolumn{2}{|c|}{$\begin{array}{l}\text { Age group 18-30 } \\
\text { Non-smokers }(n=60)\end{array}$} & \multicolumn{2}{|c|}{ Cigarette smokers $(n=29)$} & \multicolumn{2}{|c|}{$\begin{array}{l}\text { Age group } 31-85 \\
\text { Non-smokers }(n=93)\end{array}$} & \multicolumn{2}{|c|}{ Cigarette smokers $(n=26)$} \\
\hline & Mean & $( \pm S D)$ & Mean & $( \pm S D)$ & Mean & $( \pm S D)$ & Mean & $( \pm S D)$ \\
\hline $\begin{array}{l}\text { Whole blood selenium }(\mu \mathrm{g} / \mathrm{l}) \\
\text { Plasma selenium }(\mu \mathrm{g} / \mathrm{l}) \\
\text { Erythrocyte selenium }(\mu \mathrm{g} / \mathrm{g} \mathrm{Hb}) \\
\text { GSH-Px }(\mathrm{U} / \mathrm{g} \mathrm{Hb})\end{array}$ & $\begin{array}{l}135 \cdot 4 \\
114 \cdot 3 \\
0 \cdot 477 \\
19 \cdot 6\end{array}$ & $\begin{array}{l}(14.69) \\
(13.69) \\
(0.065) \\
(4.64)\end{array}$ & $\begin{array}{l}137 \cdot 0 \\
112 \cdot 5 \\
0 \cdot 490 \\
20 \cdot 7\end{array}$ & $\begin{array}{l}(18.05) \\
(14.38) \\
(0.081) \\
(5.05)\end{array}$ & $\begin{array}{l}140 \cdot 8 \\
119 \cdot 8 \\
0 \cdot 489 \\
20 \cdot 7\end{array}$ & $\begin{array}{l}(19.23) \\
(15.68) \\
(0.086) \\
(5.55)\end{array}$ & $\begin{array}{c}* * * 122 \cdot 2 \\
* * 108 \cdot 1 \\
* * * \quad 0 \cdot 411 \\
* \quad 17 \cdot 8\end{array}$ & $\begin{array}{l}(13 \cdot 21) \\
(12 \cdot 53) \\
(0.054) \\
(4 \cdot 41)\end{array}$ \\
\hline
\end{tabular}

Significantly lower ${ }^{*} p<0.02$ GSH-Px activity was found in cigarette smokers aged over 30 . In the same group highly significant differences $* *$ p $=0.001$ and ${ }_{* * *} p=0.0001$ were found for the selenium concentrations.

weekend drinkers (table 4). No difference was. apparent for the mean Se concentrations of the weekend drinkers compared with the non-drinkers.

The mean concentrations of GSH-Px activity and concentrations of $\mathrm{Se}$ in whole blood, plasma, and erthrocytes were lower in male cigarette smokers compared with non-smokers. These differences were highly significant provided that the men were over 30 (table 5). Since the above groups also included alcohol drinkers the data were reanalysed to test the effect of smoking on Se concentrations in a non-drinking group. Although the mean whole blood Se concentration for male cigarette smokers who were non-drinkers $(n=10, \bar{x}=128 \cdot 4 \pm 16 \cdot 37)$ was lower than that found in a male non-smoking, non-drinking group $(n=43, \bar{x}=139.2 \pm 22 \cdot 62)$, this difference did not reach significance. In contrast none of the results in comparable female groups showed any significant difference except for cigarette smokers who were daily drinkers compared with a non-smoking, non-drinking group. In this case the mean plasma Se values for the smokers $(n=14 \bar{x}$, $=106 \cdot 2 \pm 11.49)$ differed significantly $(p<0.05)$ compared with the non-smokers $(n=44$, $\bar{x}=115 \cdot 9 \pm 16 \cdot 61)$.

The effect of oral contraceptives on Se status was assessed in women aged under 46 (table 6). We were unable to show any effect on GSH-Px activities, but the concentration of plasma Se was significantly higher in women taking oral contraceptives.

\section{Discussion}

The reference ranges for Se concentrations in this study are similar to those found in other areas of the UK. ${ }^{14}{ }^{15}$ The Se concentrations are higher than those reported for New Zealand ${ }^{20}$ and Finland ${ }^{21}$ but lower than those found in Canada ${ }^{22}$ and the US. ${ }^{23}$

Such differences may be explained in terms of geographical variations in the concentration of Se in the soil. ${ }^{1}$ We have been unable to show any significant difference in the mean levels of GSH-Px activity or whole blood and plasma Se concentrations between men and women. There was however, a significant difference when erythrocyte Se concentrations were compared in the two groups but this is probably due to the higher erythrocyte concentrations normally found in men.

Table 6 Effect of oral contraceptions on selenium values in women under 46

\begin{tabular}{|c|c|c|c|c|}
\hline \multirow[b]{2}{*}{ Analysis } & \multicolumn{2}{|c|}{$\begin{array}{l}\text { Control group } \\
(n=61)\end{array}$} & \multicolumn{2}{|c|}{$\begin{array}{l}\text { Oral contraceptive } \\
\text { group }(n=45)\end{array}$} \\
\hline & Mean & $( \pm S D)$ & Mean & $( \pm S D)$ \\
\hline $\begin{array}{l}\text { Whole blood selenium }(\mu \mathrm{g} / \mathrm{l}) \\
\text { Plasma selenium }(\mu \mathrm{g} / \mathrm{l}) \\
\text { Erythrocyte selenium }(\mu \mathrm{g} / \mathrm{g} \mathrm{Hb}) \\
\text { GSH-Px activity }(\mathrm{U} / \mathrm{g} \mathrm{Hb})\end{array}$ & $\begin{array}{c}136 \cdot 2 \\
113 \cdot 4 \\
0 \cdot 504 \\
19 \cdot 1\end{array}$ & $\begin{array}{l}(17 \cdot 11) \\
(15 \cdot 92) \\
(0 \cdot 078) \\
(4 \cdot 32)\end{array}$ & $\begin{array}{c}142 \cdot 7 \\
* 121 \cdot 4 \\
0 \cdot 514 \\
19 \cdot 1\end{array}$ & $\begin{array}{l}(18.45) \\
(16.60) \\
(0.081) \\
(5.00)\end{array}$ \\
\hline
\end{tabular}

Mean concentration of selenium in plasma was significantly higher in the oral contraceptive group compared with the controls * $p<0.02$. 
The reference range for GSH-PX activity reported by Beutler for an American population ${ }^{17}$ is higher than that found in this study, using the same method. This may be related to the lower Se values found in the United Kingdom but Beutler also suggested that there might be ethnic differences in GSH-Px activity owing to the existence of a low GSH-Px polymorphism ${ }^{24}$; this could also account for the different ranges. Several workers have discussed the relationships between GSH-Px activity and Se status $^{25-27}$; but we have not found a significant correlation in this study. We have, however, shown that in children with phenylketonuria receiving a diet containing a very low content of Se there was a significant correlation (B Lloyd et al, unpublished observations). These children had whole blood Se concentrations under $80 \mu \mathrm{g} / \mathrm{l}$ and this confirms the report by Rea $e^{2} a^{28}$ that only low blood Se concentrations correlate with GSH-Px activities. Other studies have used different assay conditions for measuring enzyme activity and this may influence the reported relationship between GSH-Px and Se status.

In an early study Dickson and Tomlinson ${ }^{22}$ found a decline in plasma and cell Se concentrations with age, while Kasperak et $a l^{29}$ noted a gradual rise in serum Se to the age of 35 years followed by a gradual decline. In the present study we have found a significant decline in whole blood and erythrocyte Se concentrations occurring only after age 55 (table 3 ). In view of this interesting finding the dietary intakes of the oldest subjects were assessed by a dietitian who found that they were satisfactory. The lower Se concentrations in the older age group therefore may be due to less efficient absorption or increased excretion.

The effects of chronic ethanol ingestion on metabolism are wide ranging and increased urinary losses of $\mathrm{Zn}, \mathrm{Ca}, \mathrm{Mg}$, and $\mathrm{PO}_{4}$ have been reported after alcohol consumption. ${ }^{30}$ Aaseth et $\mathbf{l}^{31}$ reported decreased serum Se concentrations in 11 patients with alcoholic cirrhosis and suggested that an alteration in the metabolism of Se might cause increased urinary or faecal loss. In our study the Se concentrations of the three alcohol groups were studied in a non-smoking population. Only daily drinkers in the male group showed a significant difference in plasma Se concentrations compared with the other two groups (table 4). There was no significant difference between any of the female groups.

The most interesting finding to emerge from this study is the highly significant difference in Se status (all parameters) of men over 30 who are cigarette smokers compared with those who are non-smokers (table 5). No significant differences were found in smokers compared with non-smokers in a male non-drinking group. This may possibly be because so few cigarette smokers were also non-drinkers $(n=10)$. Comparable differences were not found in women, which is difficult to explain. These findings are contrary to those reported in a study in a New Zealand population. ${ }^{32}$ Absorbed $\mathrm{Se}$ is first carried mainly in the plasma from which it enters all tissues, and any absorbed Se taken up by the red cells requires chemical transformation before being bound again to plasma protein. ${ }^{2}$ The complex interrelationship between cadmium (Cd) and Se has been reviewed by Magos and Webb. ${ }^{33}$ They suggested that the formation of a Cd Se complex may render selenoglutathione (GS Se SG) an essential in intermediate in the metabolism of $\mathrm{Se}_{3}{ }^{2-}$ to $\mathrm{Se}^{2-}, \overrightarrow{0}$ unavailable either for uptake by the erythrocytes or for interaction with blood proteins. This hypothesis would also account for the lowered concentrations of Se found in the blood of cigarette smokers, as these are known to have high concentrations of tissue cadmium. ${ }^{34}$ We are unable to explain the difference between the Se levels found in male and female cigarette smokers.

In contrast with the findings of Capel et al ora contraceptives had no effect of GSH-Px activity. We have observed, however, a significant increase if $c$ the concentrations of plasma Se. Carbohydrate protein, lipid, and steroid metabolism are altered bo oral contraceptives ${ }^{35}$ and the slight increase in St values may reflect changes in protein metabolism, in particular an increase in several carrier protein concentrations.

We have shown that age, alcohol consumption, smoking, and oral contraceptives are all important factors that influence blood Se status. The effect of alcohol consumption on the heart has been reviewed by Alderman and Coltart, ${ }^{26}$ and the association between smoking and heart disease is well established. ${ }^{37}$ The possible additive effects of cigarette smoking and alcohol consumption on $\mathrm{Se}$ status in men over 30 is therefore particularly important, especially in view of the recent study by Salonen et $^{\mathbf{1 3}} \mathbf{}^{\mathbf{1 3}}$ relating low concentrations of serum Se with cardiovascular death and myocardial infarction. At the present time we are unable to explain the mechanisms by which these changes take place, and further study is required to produce satisfactory explanations.

We should like to thank all the subjects who volunteered to take part in the study, in particular the management and staff of Marks and Spencer Ltd and the Ordnance Survey, Southampton. We also thank the staff of the haematology department, 
Southampton General Hospital, who performed the haematological measurements, and Miss L Snow for typing the manuscript.

Correspondence to Mrs B Lloyd, University Unit of Chemical Pathology and Human Metabolism, Level D, South Laboratory and Pathology Block, Southampton General Hospital, Tremona Road, Southampton SO9 4XY.

\section{References}

${ }^{1}$ Burk RF. Selenium in man. In: Prasad AS, Oberleas D, eds. Trace elements in human health and disease. Vol II. Essential and toxic elements. New York: Academic Press, 1976: 105-33.

${ }^{2}$ Underwood EJ. Selenium. Trace elements in human and animal nutrition. 4th ed. New York: Academic Priess, 1977: 302-46.

${ }^{3}$ Flohé L, Günzler WA, Loschen G. The glutathione peroxidase reaction: a key to understand the selenium requirement of mammals. In: Kharasch $\mathrm{N}$, ed. Trace elements in health and disease. New York: Raven Press, 1979: 263-86.

${ }^{4}$ Godwin KO. Abnormal electrocardiograms in rats fed low selenium diet. $Q J$ Exp Physiol 1965; 50: 282-8.

${ }^{5}$ Godwin KO, Fraser JF. Abnormal electrocardiograms, blood pressure changes and some aspects of the histopathology of selenium deficiency in lambs. $Q J$ Exp Physiol 1966; 51: 94-102.

${ }^{6}$ Van Vleet JF, Ferrans VJ, Ruth GR. Ultrastructural alterations in nutrional cardiomyopathy of selenium-vitamin E deficient swine. Lab Invest 1977; 37: 188-211.

${ }^{7}$ Shamberger RJ, Tytko SA, Willis CE. Selenium and heart disease. In: Hemphill DD, ed. Trace substances in environmental health-IX. Columbia: University of Missouri, 1975: 15-22.

${ }^{8}$ Shamberger RJ, Gunsch MS, Willis CE, McCormack IJ. Selenium and heart disease. II-Selenium and other trace metal intakes and heart disease in 25 countries. In: Hemphill DD, ed. Trace substances in environmental health-XII. Columbia: University of Missouri, 1978: 48-52.

${ }^{\circ}$ Van Rij AM, Thomson CD, McKenzie JM, Robinson MF. Selenium deficiency in total parenteral nutrition. Am J Clin Nutr 1979; 32: 2076-85.

${ }^{10}$ Collip PJ, Chen SY. Cardiomyopathy and selenium deficiency in a two year old girl. N Engl J Med 1981; 304: 1304-5.

"Johnson RA, Baker SS, Fallon JT, et al. An occidental case of cardiomyopathy and selenium deficiency. $N$ Engl J Med 1981; 304: 1210-2.

${ }^{12}$ Keshan Disease Research Group of the Chinese Academy of Medical Sciences. Observations on the effect of sodium selenite in prevention of Keshan disease. Chin Med J 1979; 92: 471-6.

${ }^{13}$ Salonen JT, Alfthan G, Huttunen JK, Pikkarainen J, Puska P. Association between cardiovascular death and myocardial infarction and serum selenium in a matched pair longitudinal study. Lancet 1982 ; ii: 175-8.

${ }^{14}$ Fell GS, Shenkin A, Main A, Russel R, Brown A, Ottaway JM. Human selenium deficiency. Proc Nutr Soc 1980; 39: 36A.

${ }^{15}$ Capel ID, Jenner M, Williams DC, Donaldson D, Nath A. The effect of prolonged oral contraceptive steroid use on erythrocyte glutathione peroxidase activity. J Steroid Biochem 1981; 14: 729-32.
${ }^{16}$ Shaper AG, Pocock SJ, Walker M,et al. Effects of alcohol and smoking on blood lead in middle aged British men. Br Med J 1982; 284: 299-302.

${ }^{17}$ Beutler E. Glutathione peroxidase (GSH-Px). Red cell metabolism. A manual of biochemical methods. 2nd ed. New York: Grune and Stratton, 1979: 71-3.

${ }^{18}$ Lloyd B, Holt P, Delves HT. Determination of selenium in biological samples by hydride generation and atomic absorption spectroscopy. Analyst 1982; 107: 927-33.

${ }^{19} \mathrm{Nie} \mathrm{NH}$, Hull CH, Jenkins JG, Steinbrenner K, Bent DM. Statistical package for the social sciences. 2nd ed. New York: McGraw-Hill, 1975.

${ }^{20}$ Thomson CD, Robinson MF. Selenium in health and disease with emphasis on those aspects peculiar to New Zealand. Am J Clin Nutr 1980; 33: 303-23.

${ }^{21}$ Westermarck T, Raunu P, Kirjarinta M, Lappalainen L. Selenium content of whole blood and serum in adults and children of different ages from different parts of Finland. Acta Pharmacol Toxicol 1977; 40: 465-75.

${ }^{22}$ Dickson RC, Tomlinson RH. Selenium in blood and human tissues. Clin Chim Acta 1967; 16: 311-21.

${ }^{23}$ Allaway WH, Kubota J, Losee F, Roth M. Selenium, molybdenum and vanadium in human blood. Arch Environ Health 1968; 16: 342-8.

${ }^{24}$ Beutler E, Matsumoto F. Ethnic variations in red cell glutathione peroxidase activity. Blood 1975; 46: 103-10.

${ }^{25}$ Lane HW, Dudrick S, Warren DC. Blood selenium levels and glutathione peroxidase activities in university and chronic intravenous hyperalimentation subjects. Proc Soc Exp Biol Med 1981; 167: 383-90.

${ }^{26}$ Pleban PA, Munyani A, Beacham J. Determination of selenium concentration and glutathione peroxidase activity in plasma and erythrocytes. Clin Chem 1982;28: 311-6.

${ }^{27}$ Lombeck I, Kasperak K, Harbisch HD, Feinendegen LE, Bremer HJ. The selenium state of healthy children. Eur J Pediatr 1977; 125: 81-8.

${ }^{28}$ Rea HM, Thomson CD, Campbell DR, Robinson MF. Relation between erythrocyte selenium concentrations and glutathione peroxidase activities of New Zealand residents and visitors to New Zealand residents and visitors to New Zealand. Br J Nutr 1979; 42: 201-8.

${ }^{29}$ Kasperak K, Shicha H, Siller V, Feinendegen LE. Normalwerte von spurenelementen im menschlichen serum und korrelation zum lebensalter und zur serum-eiweiss-konzentration. Strahlentherapie 1972; 143: 468-72.

${ }^{30}$ Morgan MY. Alcohol and nutrition. Br Med Bull 1982; 38: 21-9.

${ }^{31}$ Aaseth J, Thomassen Y, Alexander J, Norheim G. Decreased serum selenium in alcoholic cirrhosis. $N$ Engl J Med 1980; 303: 944-5.

${ }^{32}$ Kay RG. Blood selenium values in an adult Auckland population group. NZ Med J 1979; 90: 11-3.

${ }^{33}$ Magos $L$, Webb M. The interactions of selenium with cadmium and mercury. In: Goldberg L. ed. Critical reviews in toxicology. Vol 8 . Cleveland, Ohio: CRC Press, 1980: 1-42.

${ }^{34}$ Lewis GP, Jusko WJ, Coughlin LL, Hartz S. Contribution of cigarette smoking to cadmium accumulation in man. Lancet 1972; i: 291-2

${ }^{35}$ Weindling $\mathrm{H}$, Henry JB. Laboratory test results altered by 'the pill'. JAMA 1974; 229: 1762-8.

${ }^{36}$ Alderman EL, Coltart DJ.Alcohol and the heart. Br Med Bull 1982; 38: 77-80.

${ }^{37}$ Reid DD, Hamilton PJS, McCartney P, Rose G, Jarrett $\mathrm{RJ}$, Keen $\mathrm{H}$. Smoking and other risk factors for coronary heart disease in British civil servants. Lancet 1976; i1: 979-84. 